Nikolay Hrissimov (Veliko Tărnovo)

(iD) https://orcid.org/0000-0002-9084-667X

\title{
On the Origins of Komitats in The First Bulgarian EMpIRE
}

We do not know when exactly Khan Kroum assumed power (circa 796-814), but at the beginning of his reign he found a stabilized Bulgarian state. The newly created situation also involved a change in the internal organization

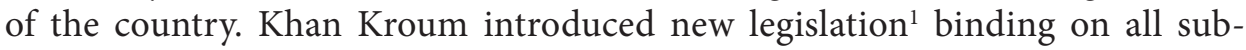
jects of the state, which came to replace the former tribal law ${ }^{2}$. This was accompanied by the administration of the newly conquered Byzantine territories, which is well illustrated by the Hambarli inscription ${ }^{3}$. Apparently, the whole state needed new administration, and that was going to be the komitats ${ }^{4}$. The earliest reliable account of the division of the Bulgarian state into komitats (ten in number) is provided by Hincmar for the year $866^{5}$. It is within the time frame between the carving of the Hambarli inscription and Hincmar's account that the emergence of komitats on Bulgarian territory must be sought.

In his classic Istoriya na Balgarskata Darzhava prez Srednite Vekove [History of the Bulgarian State in the Middle Ages], Vassil Zlatarski mentions only in passing the existence of komitats when discussing the revolt of the boyars after the conversion to Christianity ${ }^{6}$. Further on, in relation to the coming of the Komitopuli (Cometopuli) ${ }^{7}$ dynasty to the political scene, he elaborates at length on the

\footnotetext{
${ }^{1}$ Suidae Lexicon, [in:] FGHB, vol. V, p. 310.

${ }^{2}$ И. Божилов, В. ГюзЕлев, История на средновековна България VII-XIV век, София 1999, p. 140; М. АндРевв, Ф. МилковА, История на българската феодална държава и право, София 1993, p. 27-29; Ф. МилковА, Законодателството на хан Крум, [in:] България 1300. Институиии и държавна традииия, vol. II, ed. Е. БужАшки, София 1982, p. 242.

${ }^{3}$ В. Бешевлиев, Пгрвобългарски надписи, ${ }^{2}$ София 1992, р. 186-193.

${ }^{4}$ Д. Ангелов, Административно-военна уредба, [in:] История на България в четиринадесет тома, vol. II, Първа българска държава, ed. ІDEм, София 1981, p. 179-180.

${ }^{5}$ Annales Bertiniani, [in:] FLHB, vol. II, p. 287.

${ }^{6}$ В.Н. ЗлАТАРСКИ, История на българската държава през средните векове, vol. I, Първо българско изарство, pars 2, От славянизацията на държавата до падането на Пврвото изарство, София 1927 [repr. 1994], p. 45, 51.

${ }^{7}$ The name of the Komitopuli dynasty and the term komit (pl. komiti) have been rendered in the text in their native Bulgarian spellings in order to highlight their common origin.
} 
problem of the origin of the name Komitopuli. Examining the context in which it was used, he assumes that the lexeme was not used in its Byzantine meaning ${ }^{8}$,

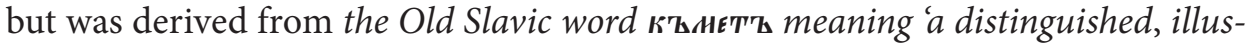
trious person who held a prominent place in society and hence in the army'.

It was not until the 1970s that the problem of the internal organization of the First Bulgarian Empire attracted greater interest and started to be investigated as the subject of research studies. Thus, in his monograph Srednovekovnata Balgarska Darzhava: uredba, harakteristika, otnosheniya sas sasednite narodi [The Medieval Bulgarian State: Organization, Characteristics, Relations with Neighbouring Peoples], Hristo Kolarov addressed the problem of komitats alongside the problems of the governance of the state and its representatives and structures. In his view the internal reformation of the state was initiated by Kroum, but it was really fulfilled by Omurtag and his heirs to the throne ${ }^{10}$. The reform involved the division of the country into districts called komitats which were entrusted to komiti ${ }^{11}$ who were appointed by the ruler to carry out the administrative and civil governance, while their most superior military leaders were the tarkans. Although for Hristo Kolarov the exact number of the komitats cannot be established, he nevertheless specifies the existence of the following komitats: Danube-Tisa, Belgrade, Braniche-

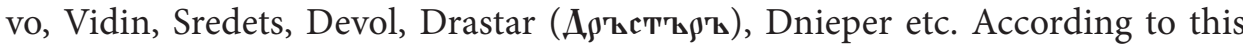
author, like a wreath, they surrounded the Bulgarian lands in Moesia and Thrace - which were set apart in a main, autonomous unit known by the name 'the Centre' or 'the Inner District'. The komitats functioned both as administrative districts and as border barriers that were the first to come under enemy attacks, and only if they could not repulse them using their own forces, the central army went into action ${ }^{12}$.

The first to come up with a specific suggestion concerning the time of emergence and nature of the komitats was the great Polish medievalist Tadeusz Wasilewski ${ }^{13}$. In his view the Bulgarian komitats came into existence simultaneously with the Christianization of the state, and what was mentioned in Responsa Nicolai ad consulta Bulgarorum as non bonam vos eis legem applies to this new administrative division rather than to the limitations imposed by Christianity ${ }^{14}$. He believes that the territories of the komitats coincided with the territories of the corresponding ecclesiastical dioceses, indirect evidence for which he finds in some hagiographical texts, but he does not specify them. In this way, the ecclesiastical

\footnotetext{
${ }^{8}$ В.Н. ЗЛАТАРСКИ, История..., р. 634.

${ }^{9}$ Ibidem, p. 635.

${ }^{10} \mathrm{Xp.} \mathrm{КолАров,} \mathrm{Средновековната} \mathrm{българска} \mathrm{дьржава} \mathrm{(уредба,} \mathrm{характеристика,} \mathrm{отношения}$ със съседните народи), Велико Търново 1977, р. 7-8.

${ }^{11}$ On the spelling of the term komit (pl. komiti) see note 7 above.

${ }^{12}$ Хр. КолАров, Средновековната българска държава..., p. 8.

${ }^{13}$ T. WAsILEWski, Origine de l'organisation administrative des "comitates" en Bulgarie medievale, EB $14,1,1978$, p. 84-88.

${ }^{14}$ Ibidem, p. 85.
} 
organization was superimposed on political culture, and this was a characteristic feature not only of the Bulgarian state ${ }^{15}$. This in turn, according to Wasilewski, makes it possible to establish the number of komitats, which corresponded to the number of dioceses ${ }^{16}$. For him the model of komitats can be sought in the neighbouring regions situated on the periphery of the Kingdom of the Franks - the Duchy of Bavaria, Carantania and the Duchy of Friuli ${ }^{17}$.

Coinciding with Wasilewski, in Bulgaria Ivan Venedikov was the first to bring the question of the military and administrative organization of the early medieval Bulgarian state to the forefront ${ }^{18}$. According to Venedikov, the Komitat of Sredets was the first that was established. Following a line of reasoning based on indirect evidence, he arrived at the conclusion that it was set up by Khan Kroum and suggested that the title of komit was borne by the local Byzantine governor and was later on adopted by the Bulgarians and the new local governor ${ }^{19}$. Regarding the origin of the title, he points out several times that in Latin komit and komitat mean 'count' and 'county' respectively ${ }^{20}$. Furthermore, Venedikov emphasizes the fact that the late Roman title comes (pl. comites) was also kept in Byzantium where the

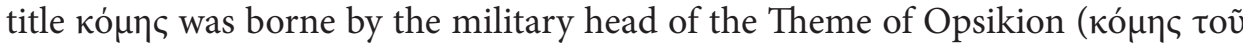
'O४⿻кíov) and of the one of South Italy and Sicily, stressing the point that a large number of Balkan Slavs were settled in the Theme of Opsikion at the end of the $7^{\text {th }}$ century. And while for Venedikov the use of this title is easily explicable about Latin-speaking Italy, this is not the case about the interior of Byzantium where the Theme of Opsikion was situated. He tries to offer an explanation which, however, he himself finds not satisfactory: that the word was probably also used in the old province of Thrace where the Slavs who were settled in Opsikion hailed from. Thus he assumes that the title was of Byzantine origin ${ }^{21}$, but notes that in inscriptions instead of кó $\mu\rceil$, the word in nominative is spelled кó $\mu \eta \tau \varsigma^{22}$.

Regarding the problems of centralism and regionalism in the First Bulgarian Empire, Georgi Nikolov also directs his attention to some problems related to komitats. He notes that komit was one of the few Byzantine titles which found their way into and were established in the Bulgarian administrative system during the $9^{\text {th }}-10^{\text {th }}$ centuries $^{23}$, with the new administration of the Bulgarian lands beginning

\footnotetext{
${ }^{15}$ Ibidem, p. 86-87.

${ }^{16}$ Ibidem, p. 87.

${ }^{17}$ Ibidem.

${ }^{18}$ И. Венедиков, Военното и административното устройство на България през IX и X век, София 1979.

${ }^{19}$ Ibidem, p. 77-80, and especially p. 80 .

${ }^{20}$ Ibidem, p. 56, 65.

${ }^{21}$ Ibidem, p. 65-66.

${ }^{22}$ Ibidem, p. 66.

${ }^{23}$ Г.Н. Николов, Централизъм и регионализъм в ранносредновековна България (края на VII - началото на XI в.), София 2005, р. 89-90.
} 
as early as the reign of Khan Kroum ${ }^{24}$. Special mention must be made of his point that the komitats in some cases governed compact masses of non-Bulgarian population (meaning the Byzantine population resettled beyond the River Danube) ${ }^{25}$.

A new, summarizing study on the problem of komitats appeared almost 30 years after Ivan Venedikov's piece of research. Entitled Balgariya $i$ Vizantiya. Voenna Administratsiya VII-IX v. [Bulgaria and Byzantium: $7^{\text {th }}-9^{\text {th }}$ Centuries Military Administration], Zhivko Zhekov's monograph focuses particularly on komitats. He assumes that the earliest evidence (although dated ambiguously) giving information about the existence of komitats in the Bulgarian state is the one about the Byzantine captives settled in 'Bulgaria beyond the Danube' and their revolt against the local authorities headed by a кó $\mu \eta \varsigma^{26}$. Based on this assumption, the author tries to date this first mention and hence the emergence of komitats in early medieval Bulgaria. Doubting the reliability of the information about the Bulgarian rulers Vladimir and Michael the Bulgarian mentioned there, Zhekov relies on the other ruler mentioned - the Byzantine Emperor Theophilos (813-842), and dates the event to the first years of Khan Presian's reign ${ }^{27}$. Basing his analysis on this piece of information and examining retrospectively the events and the Bulgarian rulers who reigned during the period, he reaches the conclusion that the emergence of komitats should be dated to the reign of Khan Omurtag $(814-831)^{28}$. The author finds evidence in support of his argument in the uprising of the Timociani $^{29}$, citing the setting up of komitats as the reason (and cause) for their breaking away ${ }^{30}$, while he believes the term rectores in Annales regni Francorum is to be understood as komeses ${ }^{31}$. According to Zhekov, the fact that Hincmar mentioned ten komitats does not mean that they had all been established simultaneously, but it was apparently a gradual process ${ }^{32}$. Venedikov's thesis that the first komitat to

\footnotetext{
${ }^{24}$ Ibidem, p. 91.

${ }^{25}$ Ibidem, p. 90.

${ }^{26}$ Leonis Grammatici Chronographia, [in:] FGHB, vol. V, p. 156-157; Pseudo-Symeonis Chronographia, [in:] FGHB, vol. V, p. 172; Georgius Monachus Continuatus, [in:] FGHB, vol. VI, p. 136-137. Ж. ЖЕков, България и Византия. Военна администрация VII-IX в., София 2007, p. 255-256. One should bear in mind that this particular evidence comes from the works of historians from the circle of the Emperor Constantine Porphyrogennetos which provide no credible evidence about the Bulgarians: the information about them is severely distorted and of legendary character. Cf.,

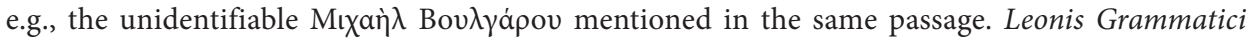
Chronographia, p. 156.

27 Ж. Жеков, България и Византия..., р. 256.

${ }^{28}$ Ibidem, p. 256-257.

${ }^{29}$ Ibidem, p. 257.

${ }^{30}$ Ibidem, p. 258.

${ }^{31}$ Ibidem, p. 258, 259, 260. Further in the text, probably under the influence of the use of komes in the piece of information under consideration in Leo the Grammarian about the Byzantines settled beyond the Danube, the author consistently calls komiti by the Greek term 'komeses'.

${ }^{32}$ Ibidem, p. 257-258.
} 
be established was that of Sredets is considered unfounded by Zhekov because of lack of evidence about any Byzantine komeses in the Balkans, while the other position of komes in the Byzantine army - a commander of a 150-400 strong unit - was a rank too low for a commander of such a strategically located city ${ }^{33}$.

Zhekov advances the thesis that there was a direct relationship between the Bulgarian military activity in the north-east and the emergence of the first komitats. The Byzantines that were settled in the Bulgarian lands beyond the Danube, on the one hand, increased the population of these sparsely populated territories, while at the same time acting as a buffer against the Pechenegs and Magyars advancing from the east, but on the other hand, they also created problems, the most serious, according to Zhekov, being the spread of Christianity ${ }^{34}$. The author's thesis is that setting up a komitat with the aim of controlling the Byzantines settled there and their loyalty to the state was one of the possible ways for the central authority to maintain control of these territories ${ }^{35}$. For him this means that the establishing of such a komitat should be dated to before the beginning of the campaign towards the Dnieper during which the kopan Korsis perished ${ }^{36}$, and also before the campaign against Thomas the Slav. In Zhekov's opinion, the campaign against Thomas the Slav required special preparations in the rear areas so that Bulgarian troops did not have to fight simultaneously on two fronts. Drawing attention to the fact that the uprising of Thomas began in 819-820, while Omurtag intervened in 823, the author accepts that Byzantium at that time could not be actively engaged in foreign politics and this was a suitable time for a military campaign in the north-east, the preparations for which also involved the setting up of this komitat ${ }^{37}$. The preparations for the campaign against Thomas the Slav, so the argument goes, began with the building of the aul at the River Ticha serving as a base and starting point for the advance to the south. The building of this aul, according to the author, has been dated reasonably precisely to 821-822. For him this date can be accepted as terminus ante quem for organizing the komitat controlling the River Danube delta, that is, its establishment was in the period 818-821, and this komitat provided a model for the setting up of the next ones ${ }^{38}$.

On the origins of komitats as a system Zhekov avoids taking a view, citing lack of concrete evidence in the sources about using the institutional models of neighbouring states. He makes a comparison with the possible sources of the model ${ }^{39}$. With steppe empires (Turks, Avars and Khazars) his research does not reveal

\footnotetext{
${ }^{33}$ Ibidem, p. 260-261.

${ }^{34}$ Ibidem, p. 261-264.

${ }^{35}$ Ibidem, p. 264.

${ }^{36}$ Cf. В. БЕшевлиев, Първобългарски надписи..., p. 227-229 (nо. 59).

37 Ж. Жеков, България и Византия..., р. 264.

${ }^{38}$ Ibidem, p. 264.

${ }^{39}$ Ibidem, p. 279.
} 
any points of contact ${ }^{40}$. The relation of komitats to the Frankish counties because of possible Latin origin of the word komit is considered unlikely, an observation further supported by the differences in the way of life of the leading ethnic elements in the two states, Proto-Bulgarians and Franks - nomads and settled population respectively, and the almost non-existent contacts between the two states before the reign of Khan Omurtag ${ }^{41}$. Byzantine influence, in particular the theme system, is found in the principles that were applied - the stationing of military units in komitats, but also considered are the big differences in the komiti's functions compared to the ones of the theme strategoi ${ }^{42}$.

In her summarizing monograph on the early medieval Bulgarian ruler and the state administration of the First Bulgarian Empire, Tatiana Slavova notes at the very beginning of the review of the available information on komiti that this was 'certainly a Greek title', and already in the title of the paragraph designates it as $\kappa o ́ \mu \eta \varsigma^{43}$. A comprehensive review of all the mentions of komiti known from sources is done $e^{44}$, and using the descriptions of their functions according to the texts, an attempt is made to define the nature of their duties in the early medieval Bulgarian state. This review, however, shows that the author confuses the functions of the komes as governor of a district with those of the komes as commander of a band in the Byzantine army ${ }^{45}$. A survey on the uses of the lexeme in Old Bulgarian trans-

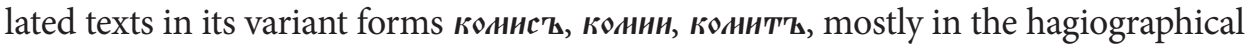
literature, indicates that it was mainly a substitute for prefect of a province from the original texts, while the rendering of patrikios as конист, and on one occasion even as $\kappa^{\mathbf{Z}} \mathbf{\mathbf { Z }} \mathbf{\mathrm { A }} \mathbf{3} \mathbf{3} \mathbf{\mathbf { Z }}$, is further proof of the title's high status ${ }^{46}$, completely ruling

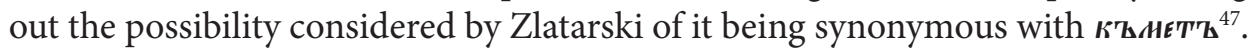

Summarizing the leading views on the origin of komitats presented here - those of Kolarov, Wasilewski, Venedikov and Zhekov, a number of flaws become evident. This points to the conclusion that the topic cannot be considered exhausted and there are many questions about the internal division of the early medieval Bulgarian state that have not been answered and need to be dealt with. It is for this reason that attention should be paid to the flaws in their theories, after which another hypothesis about the emergence of the system of komitats on the territory of the First Bulgarian Empire will be proposed.

\footnotetext{
${ }^{40}$ Ibidem, p. 280-281.

${ }^{41}$ Ibidem, p. 281.

${ }^{42}$ Ibidem, p. 282.

${ }^{43}$ Т. СлАвовА, Владетел и администрачия в ранносредновековна България. Филологически аспекти, София 2010, p. 153.

${ }^{44}$ Ibidem, p. 155.

${ }^{45}$ Ibidem, p. 156-157.

${ }^{46}$ Ibidem, p. 157-158.

${ }^{47}$ On the origin and meaning of къметъ, sеe Р. СТАнков, О лексических моравизмах в древних славянских рукописях, [in:] ПКШ, vol. IX, p. 40-41.
} 
Clearly discernible in Venedikov's theory is the internal contradiction which troubled him when offering an explanation as to where the system of komitats in the early medieval Bulgarian state could have been borrowed from. On the one hand, perfectly evident to him is its relation to the Western European title count and hence the territory a count governed - county; on the other hand, he also puts forward an explanation he finds not satisfactory, and one which is quite indirect, about its relation to the Slavs from the Theme of Thrace settled in Opsikion - the only theme on the territory of Byzantium where the title komes was used. At the same time, the author strongly emphasizes a contradiction: in Proto-Bulgarian

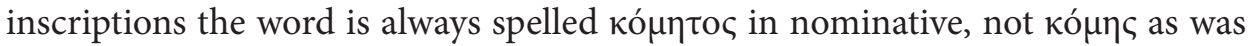
the variant form used at that time in Byzantium. A later article provides an overview of the issues of the administrative organization of the First Bulgarian Empire in which the author ignores this contradiction, only stressing the correspondence between komit and the Latin for count $t^{48}$. The article makes no mention of the fact that the first komitat to be established on the territory of early medieval Bulgaria was that of Sredets, so it can be assumed that the author has reconsidered his view on this point, too. He now discusses the gradual incorporation of new territories into the Bulgarian state in the following order: the lands between the Danube and The Carpathians; the lands between the Danube and Syrmia (Srem) along with the lands along the Struma; then with Khan Presian also the lands along the upper and middle reaches of the River Vardar etc. ${ }^{49}$ One should also consider here the reasons given by Zhekov against the possibility that the Komitat of Sredets could have been the first komitat established on Bulgarian territory, citing lack of evidence about any Byzantine komeses in the Balkans, while the other position of komes in the army was a rank too low for a commander of such a strategically located city ${ }^{50}$.

Many more are the ambiguities and contradictions noticeable in Zhekov's thesis. His thesis is based on a rather confused piece of information found in Leo the Grammarian and Georgius Monachus Continuatus about Byzantine captives moved and settled in 'Bulgaria beyond the Danube' and their flight from there at the time of the Bulgarian ruler $B a \lambda \delta^{\prime} \mu \varepsilon \rho^{51}$. Although Zhekov makes an effort to date this information relying on the Byzantine Emperor Theophilos (813-842) mentioned there, it nevertheless remains not clearly located in time. Furthermore, a detail which was only discussed by Venedikov, but Zhekov has overlooked, deserves attention. It concerns the title which the local ruler in question had. It is

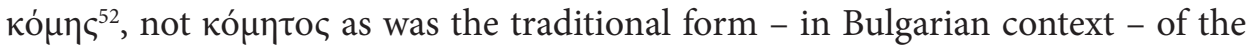

\footnotetext{
${ }^{48}$ Ив. Венедиков, Административна уредба на Първата българска държава, [in:] България 1300. Институции и държавна традиция, vol. I, ed. Ев. БужАшки, София 1981, p. 149.

${ }^{49}$ Ibidem.

${ }^{50}$ Ж. Жеков, България и Византия..., p. 260-261.

${ }^{51}$ Leonis Grammatici Chronographia, p. 156-157; Georgius Monachus Continuatus, p. 136-137. Ж. Жеков, България и Византия..., p. 255-256.

${ }^{52}$ Leonis Grammatici Chronographia, p. 156; Georgius Monachus Continuatus, p. 136.
} 
word denoting the governor of a komitat in the early medieval Bulgarian state. Going back to the two meanings of the title in Byzantine context, a governor of a theme (as an exception), and a commander of a band, it should be noted that in its second meaning, that of a low-ranking military officer, the title was not unfamiliar during the period in question on the territory of the Balkan Peninsula, and specifically to the Bulgarians. A good illustration of the fact that the Bulgar-

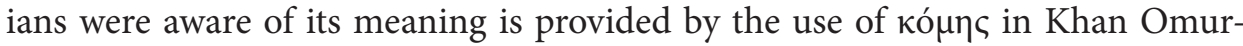
tag's inscription of Syuleymankyoy, which preserved some of the clauses of the Byzantine-Bulgarian 30-year peace treaty ${ }^{53}$. In the clause on the exchange of prisoners of war in this treaty, komeses are listed in the third place after tourmarchoi and spatharioi $i^{54}$. The order in which they are mentioned proves beyond doubt that what was meant in this particular case was commanders of bands, and thus it is quite impossible to accept кó $\eta_{\uparrow} \varsigma$ as a prototype of such a high-ranking position as komit was with the Bulgarians. Careful analysis of the context of the episode under consideration described by Leo the Grammarian and Georgius Monachus Continuatus does not allow to establish with any certainty which of the two uses of the title was specifically meant.

The search for indirect ways of determining the precise date of the emergence of what Zhekov believes was the first komitat of the early medieval Bulgarian state also reveals several weak points. His thesis is grounded in the idea that there was a connection between the Bulgarian activity in the north-east and the emergence of the first komitats. This is the perspective from which the author also sees the settling of Byzantines in the sparsely populated territories to the north-east of the River Danube delta - to act as a buffer against the surging waves of steppe peoples, in this particular case Pechenegs and Magyars. At the same time, they are viewed by him as causing problems, the most serious, according to him, being the spread of Christianity. It is hard to believe that Christianity in itself would be so dangerous in such a half-savage, heavily barbarian environment! Applying the same logic, although not being Christians, much more dangerous to Bulgaria (and to Byzantium as well) were the unconverted steppe tribes. It was not by chance that the Byzantines in question were settled opposite them. Moving population from newly conquered or rebel territories to other places with the aim of establishing buffers was a widely used method which is well known from the history of the Byzantine Empire ${ }^{55}$. It was on this method tested by the neighbouring country that

\footnotetext{
${ }^{53}$ В. БЕшевлиЕв, Първобългарски надписи..., p. 164-166 (no. 41).

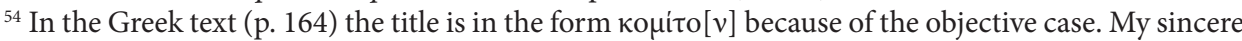
thanks go to doctoral student Simeon Antonov for his help while working with the Greek texts.

${ }^{55}$ E.g., the migration of the Mardaites (686-687) and the Slavs to Opsikion (688) during the reign of Justinian II (685-695, 705-711) - Theophanes Confessor, [in:] FGHB, vol. III, p. 265; Ю.А. КулАковский, История Византии, vol. III, (602-717 г2.), Киев 1915, p. 255-256. For a study summarizing migration during the reign of Justinian II, see Г. Острогорски, История на Византийската държава, trans. Ил. СлАвовА, София [s.a.], p. 192-194.
} 
the Bulgarian policy to resettle the Byzantine prisoners of war in the $9^{\text {th }}$ century in such buffer territories was based. The danger in this particular case was not the spread of Christianity, but the contact of the Byzantines of 'Bulgaria beyond the Danube' with the central Byzantine authority. In this way, they became potential enemies in the rear of the central Bulgarian authority. Thus, it was not the setting up of a hypothetical komitat that would have helped establish fuller control over the Byzantines resettled in the interior, but rather preventing their communication with Byzantium.

The setting up of this komitat is dated by Zhekov to before the Bulgarian campaign towards the River Dnieper during which the kopan Korsis perished, and before the campaign against Thomas the $\mathrm{Slav}^{56}$. Viewing the two conflicts as interrelated and proceeding from the principle that a state should not wage war simultaneously on two fronts, he reaches the conclusion that the most suitable time for the campaign in the north-east towards the Dnieper and the setting up of the first komitat (in his terminology, the north-eastern one) was the period between 818 and 821 . This conclusion can only be accepted in half. With the situation described, the proposed period would have been the most suitable for conducting a military campaign towards the Khazar Khaganate, but it might have had different aims and not necessarily required long preparations if dictated by unforeseen circumstances ${ }^{57}$.

\footnotetext{
${ }^{56}$ The years of the beginning of the uprising of Thomas the Slav given by Zhekov and quoted above, $819-820$, are misleading as even the specific date of its beginning is well known. The revolt began immediately after the assassination of Leo V the Armenian (813-820) during the Christmas service (see С.Б. ДАшков, Императоры Византии, Москва 1996, p. 149) when Thomas did not recognize the newly proclaimed Emperor Michael II (820-829), and the proper beginning of the uprising itself was in the spring of 821 on the border with the Abbasid caliphate (J.B. BuRY, A History of the Eastern Roman Empire from the Fall of Irene to the Accession of Basil I (A.D. 802-867), London 1912, p. 86-87), that is, it began at least a year later than the date given by the author. It is unlikely that for the mounting of a surprise attack on Thomas the Slav, who was besieging Constantinople, it was necessary for a static fort to be built which would have remained far in the rear of the Bulgarian troops during possible military operations deep into Byzantine territory. Its building would have taken up considerable time and resources, which would in no way have contributed to a surprise attack. Besides, in the Chatalar inscription itself, celebrating the building of a 'small aul' (on the problem of the identification of this 'small aul', see В. Бешевлиев, Първобългарски надписи..., p. 222-224) there is no mention of it having been built as a starting point for a military campaign, and such an important fact in view of the political situation of the time would have hardly been omitted. The expression in the inscription... to trample well the emperor underfoot... is part of a well-known Byzantine practice of acclamation of Eastern (Sasanian) origin (В. БЕшевлиев, Първобългарски надписи..., p. 82-83, 220-221) and should hardly be associated with any particular events.

${ }^{57}$ On the question of the reasons for the Bulgarian campaign towards the River Dnieper, see Н. ХРИсимов, Българската държавност в старата Родина (VII-XI в.): така наречената Черна България, [in:] Българска национална история, vol. II, Древните българи. Стара Велика България, ed. Пл. ПАвлов, Велико Търново 2013, р. 288-290.
} 
We cannot cite any instances where important state reforms were introduced before a military campaign, still less when the result of the campaign would have been difficult to predict. This is even more so with such an 'experiment' concerning elements disloyal to the state as the Byzantine settlers were, and when the result their activity would produce would have been known very well in advance. It is much more plausible and as a matter of course that reforms be introduced after a military campaign or social upheaval in the country. Regardless of their result, there would be certain lessons learned that could provide a basis for the necessary changes (reforms) to be brought about. This is how the adopting of Khan Kroum's laws is presented in the Suda - after the successful campaign against the Avars and the Bulgarian ruler's discourse with the Avar aristocrats ${ }^{58}$. And while this piece of information about Khan Kroum might sometimes be considered legendary, the information about the processes of setting up the theme system in Byzantium, which contributed to its survival after the Arab expansion and was preserved in a sustainable way until the $11^{\text {th }}$ century, by no means can be defined as legendary ${ }^{59}$. Such should have also been the situation in the case of the emergence of komitats in early medieval Bulgaria. With the inconsistencies demonstrated and arguments presented above, the thesis about the emergence of komitats in the period between 818 and 821 in the Bulgarian north-east cannot be considered acceptable.

Before we explore another possibility of borrowing the system of komitats, it is necessary to turn our attention to the condition of the Bulgarian state and the geopolitical situation in which it was placed at the end of the $8^{\text {th }}$ and the first half of the $9^{\text {th }}$ century. This was partly done at the beginning of the presentation, but the matter needs to be further examined as, to a large extent, it would provide the direction in which it is possible to seek any possible analogies with the administrative division that functioned in the First Bulgarian Empire from the $9^{\text {th }}$ century to its very demise, one that has achieved great fame due to the name of its last royal dynasty - that of the Komitopuli. Besides the internal stability achieved, Bulgaria began to pursue expansionist policy, with its first major territorial acquisitions being to the north-west at the expense of the Avar Khaganate towards the middle reaches of the River Danube and Transylvania. This expansion subsequently also continued to the west and south-east at the expense of Byzantine territories ${ }^{60}$. As a result of this more than two-fold expansion, on the territory of the Bulgarian state lived a large number of tribal and ethnic groups - that is, the state became multiethnic in character. Until that moment all those tribal and ethnic groups that

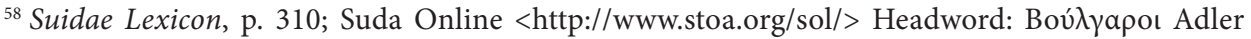
number: beta, 423 [15 VIII 2018].

${ }^{59}$ Ж. Жеков, България и Византия..., p. 186-208 and the bibliography given there.

${ }^{60}$ Seе П. КоледАров, Политическа геограбия на средновековната българска държава, vol. I, (679-1018), София 1979, р. 32-33.
} 
inhabited the Bulgarian territory settled the lawsuits and disputes between them according to the traditional law, and the Byzantines observed the Christian laws. With the aim of eliminating these differences, Khan Kroum introduced state legislation binding on all subjects of the state ${ }^{61}$. At the same time, for the first time Bulgaria was placed in a situation of having immediate neighbours, as before that there had been buffer territories between her and her neighbours ${ }^{62}$. These new neighbours included Byzantium, and later also the state of the Franks, Serbian principalities, Great Moravia, Croatia and others. The next step in the country's internal politics, which was not carried out by Khan Kroum, was the issue of the administration of its dramatically increased territory. In summary, the factors that determined the emergence of the new internal administration of Bulgaria were both internal and external, and should not be considered separately by any means, but comprehensively.

With this situation in view, we must look again at those neighbours of Bulgaria which she considered rivals at that time - Byzantium and the Frankish Empire. In the two states, the issue of their internal division and government was decided in two radically different ways. In Byzantium, the introducing of the theme

\footnotetext{
${ }^{61}$ See note 56.

${ }^{62}$ This was the situation with Byzantium until the second half of the $8^{\text {th }}$ century when Bulgarias southern neighbour began to gradually regain its territories in Thrace (see К. СтАнев, Тракия в Ранното Средновековие, Велико Търново 2012, p. 86-109), and if we take into account the Stara Planina factor (sеe П. МутАфчиев, Балканът в нашата история, [in:] IDEм, Книга за българите, ed. В. Гюзелев, София 1987, р. 65-89; К. МАРинов, Планинската верига Хемус и българската политическа граница през ранносредновековния период (Общ поглед), [in:] Балканите - език, история, култура, vol. IV, Материали от Четвъртата международна научна конферениия „Балканите - език, история, култура”, Велико Търново, 18-20 октомври 2013 г., еd. Кр. МуТАФовА, Велико Търново 2015, р. 105-120; IDEм, Стратегическата роля на Старопланинската и Средногорската вериги в светлината на българо-византийските военни сбльсъии nрез VII-XI век, ИРИМГ 2, 2014, p. 111-134; IDEм, The Haemus Mountains and the Geopolitics of the First Bulgarian Empire: An Overview, ЗРВИ 51, 2014, p. 17-32; IDEм, В дербите на Хемус (За някои страни в ролята на планината през периода VII-IX в.), Pbg 37, 4, 2013, p. 60-73; IDEм, Góry Hemos jako miejsce schronienia, baza wypadowa i punkt obserwacyjny w świetle bułgarsko-bizantyńskich zmagań zbrojnych okresu wczesnego średniowiecza, BP 20, 2013, p. 5-17), Bulgaria had at that time, too, a buffer territory to the south. To the northeast, towards the Khazars, the territories between the rivers Dniester and Dnieper in the $8^{\text {th }}$ century were not settled and acted as a buffer between the two states (sеe В. Козлов, Население степного междуречья Дуная и Днестра конца VIII - начала ХI веков н.э.: балкано-дунайская культура, Казань-Санкт-Петербург-Кишинев 2015; О.В. Комар, Хозарський каганат у VIII-X cm., [in:] Україна: хронологія розвитку. Давні слов'яни та Київська Русь, vol. II, ed. П. ТОЛОчКО, Г. ИвАКІн, О. МОЦЯ, Київ 2009, map on p. 119). To the northwest, towards the Avars, on the territory of the Central Balkans no evidence of habitation has been found dating from the $8^{\text {th }}$ century (see I. Bugarski, M. Radišić, The Central Balkans in the Early Middle Ages: Archaeological Testimonies to Change, [in:] Byzantine Heritage and Serbian Art, vol. I, Process of Byzantinisation and Serbian Archaeology, ed. V. BIKIć, Belgrade 2016, p. 91-99), and to the north of the River Danube, the Carpathian Mountains acted as a wide natural buffer separating the Bulgarians from the Avars.
} 
system, which formed the basis of its internal government, began as early as the $7^{\text {th }}$ century. In the Frankish Empire, Charlemagne introduced a new territorial division - the marches. It is clearly evident from the comprehensive review of the theme system done by Zhekov that there were no points of contact with komitats in Bulgaria ${ }^{63}$. The territorial division of the Frankish Empire - the marches as structure and principles of division, however, has remained outside of the main line of comparison and enquiry of the researchers exploring the issue. Therefore, they will be considered here in detail.

Marches as a phenomenon in the Frankish Empire emerged during Charlemagne's reign. The first three marches - those of Bretagne, Avar, and Spain, appeared during the last decade of the $8^{\text {th }}$ and the first decade of the $9^{\text {th }}$ centur $y^{64}$ and were sparsely inhabited regions surrounded by inhabited territories ${ }^{65}$ combining a frontier and a boundary ${ }^{66}$. Although first mentioned in 779 in the Capitulary of $\mathrm{Herstal}^{67}$, the term remained of limited use during Charlemagne's reign $^{68}$. At first marches were set up in the border territories newly conquered by the Franks. The territory of each of them included several counties. The marches combined military and administrative functions ${ }^{69}$. They were governed by margraves, but the latter term only came into existence as late as the $13^{\text {th }}$ century, while before that dux limitis, praefectus limitis and marchio were used. In 838 was the first mention of marchio also in the sense of governor of such a district. The term comes or comes et marchio had the same meaning ${ }^{70}$. In medieval Latin texts the title was spelled comes $^{71}$, which was due to the overlapping of the functions of margrave and those of the late antique comes civitatis $^{72}$.

${ }^{63}$ Ж. Жеков, България и Византия..., p. 186-218. The opinion expressed about some similarities with the theme system based on the coincidence that in both themes and komitats military forces were stationed is much too formal to be taken into account (see ibidem, p. 282).

${ }^{64}$ H. Wolfram, The Creation of the Carolingian Frontier-System c. 800, [in:] Transformation of Frontier from Late Antiquity to Carolingians, ed. W. Pohl, I. Wood, H. ReImitz, Leiden-Boston 2001, p. 243. ${ }^{65}$ Ibidem, p. 233.

${ }^{66}$ J.M.H. Sмiтh, Fines Imperii: The Marches, [in:] The New Cambridge Medieval History, vol. II, c. 700-900, ed. R. McCormick, Cambridge 2008, p. 176-177. The linear type of boundary is close to the modern concept of 'boundary' sharply separating a territory from another. From this point of view, a march could be either the internal boundary of a border region or a clearly defined external boundary. The zonal frontier is of the buffer zone type, in which there are uninhabited or desert lands between the territories of two states.

${ }^{67}$ In its variant form marka, the term is of Proto-Germanic origin and means 'border land' (LMA, vol. VI, p. 300) or 'edge' (H. Wolfram, The Creation..., p. 233).

${ }^{68}$ It is worth noting that the term marca was used as a synonym for limes, terminus or finis. From the way it was used, it is evident that the term was closer in meaning to frontier zone rather than to boundary. See H. Wolfram, The Creation..., p. 234.

${ }^{69}$ LMA, vol. VI, p. 300-301.

${ }^{70}$ Ibidem.

${ }^{71}$ Dictionary of the Middle Ages, vol. VIII, Macbeth - Mystery plays, New York 1987, p. 133.

${ }^{72} L M A$, vol. III, p. 76, 78. 
The march situated closest to Bulgarian territories - the Avar March, emerged after the incorporation of the lands of the Bavarian duke Tassilo III into the Frankish Empire in 788 and the setting up of the Bavarian march $^{73}$. The Franks thus became immediate neighbours with the Avars, and that same year they already had three serious military confrontations between them in the contact zones in the region of Friuli and Lower Austria ${ }^{74}$. Regardless of the continuing confrontations and the special military commanders appointed in order to protect these territories from the Avars - Eric in Friuli, subordinate to Pepin, the King of the Lombards, and Gerold, Prefect of Bavaria, directly subordinate to the Frankish King, they remained subordinate to higher-ranking governors ${ }^{75}$. According to C. Bowlus, after 799 (more likely after 803) Charlemagne sent a special margrave who was semi-independent from the Prefect of Bavaria ${ }^{76}$. To H. Wolfram, terminus ante quem for the setting up of the Avar March is 817 and the issuing of the Ordinatio imperii $i^{77}$, i.e. not later than that time it was functioning up to the north-western Bulgarian border, and after 826 was reorganized as a result of the Bulgarian invasion along the middle reaches of the Danube ${ }^{78}$.

The 'internal' independence of margraves (comes), along with their being directly subordinate to the ruler, made marches viable as territorial and administrative units of the Frankish Empire. On the one hand, the margrave was close to the points of military conflict and could react swiftly to an assault or other activity, and when necessary he could be reinforced by troops sent from the central parts of the state. On the other hand, attempts at separatism on the part of any of the margraves could quickly be neutralized by the forces of the central authority. This made the 'centre - periphery' system constituted by the central part of the Frankish Empire and the marches extremely convenient to govern and viable as structure. Seen as a whole, the system of marches did not represent any novelty but used a well-functioning old model inherited by the Roman Empire, even though there was no direct continuity between the two states. That was the model of provinces in which there was one centre of the state (Rome and the Italic Peninsula) and provinces subordinate to it.

Coming back to komitats, we need to specify all that is known (or unknown) of them. To begin with, the earliest account where komitats are mentioned - that of Hincmar of 866, tells us of the existence of ten komitats. The known sources to date have not provided us with direct or indirect evidence about the

\footnotetext{
${ }^{73}$ H. Wolfram, The Creation..., p. 237-238.

${ }^{74}$ Ibidem, p. 238.

${ }^{75}$ Ibidem, p. 239-240; C.R. Bowlus, Franks, Moravians, and Magyars: The Struggle for the Middle Danube, 788-907, Philadelphia 1995, p. 71.

${ }^{76}$ C.R. Bowlus, Franks..., p. 71.

${ }^{77}$ H. Wolfram, The Creation..., p. 239-240.

${ }^{78}$ C.R. Bowlus, Franks..., p. 90-113.
} 
internal structure of komitats or about their centres. They are referred to as located along the west and north-eastern borders of the state.

What is known about komitats is mostly based on researchers' conclusions. Regarding their functions, authors take two polarized views. According to Zlatarski, they only had military functions ${ }^{79}$, while Angelov takes the view that they were only civil governors ${ }^{80}$. More recently, based on the presence and mentioning of komiti in Old Bulgarian texts, Slavova arrives at the conclusion that they carried out both military and civil functions ${ }^{81}$. Regarding the way they were appointed to their positions, there is a divergence of opinion between different scholars. For Zlatarski, starting from the assumption that komit was derived from $\mathbf{K}^{\prime} \mathbf{z} \mathbf{M} \mathbf{m} \mathbf{T} \mathbf{z}$, they came from the local population in the komitat, were elected, and confirmed by the central authority, while others (of Proto-Bulgarian descent) were directly appointed by the ruler ${ }^{82}$. According to Angelov, however, their position was held by right of succession ${ }^{83}$. The two views presented are either based on a position on the origin of the word taken a priori (Zlatarski), or (most likely) on evidence about events or persons from the second half of the $10^{\text {th }}$ century, such as komit Nikola and the Komitopuli (Angelov).

The comparison with marches and their governors shows not a few correspondences. Worth noting also is the fact that the earliest mentions of komitats concern the north-western Bulgarian border, situated closest to the Franks. Based on the known evidence about the functions komitats served, it can be asserted confidently that they also performed, like the marches, the functions of a linear type of boundary and of a zonal frontier. And just like the marches, they brought (compulsorily) different ethnic groups [Slavic tribes, Byzantines, Avars (?) etc.] under a unified leadership appointed by the central state authority.

Similarities can also be observed between komiti and marchio (comes). Both the Frankish and Bulgarian governors performed both military and civil functions.

Despite these correspondences, the contacts between early medieval Bulgaria and the Frankish Empire/Kingdom may seem to have been quite recent if we take into account the prevailing opinion that they were only established during the second decade of the $9^{\text {th }}$ century ${ }^{84}$. Commonly ignored is, however, the information provided by Monachus Sangallensis about the conquering of the Avar seat of Hring by Pepin, Charlemagne's son in 796. He described how Charlemagne

\footnotetext{
${ }^{79}$ В.Н. ЗЛАТАРСКИ [rec.], Г. БАЛАСЧЕв, Новонайдениять надписъ оть времето на изарь Симеона... - СНУНК 15, 1898, р. 37.

${ }^{80}$ Д. Ангелов, М. Андревв, История на българската държава и право, София 1972, p. 110; Д. Ангелов, Комит, [in:] КME, vol. II, И-O, ed. П. Динеков, София 1995, p. 384.

${ }^{81}$ Т. СлАвОвА, Владетел... p. 156-157.

${ }^{82}$ В.Н. ЗЛАТАРСКИ, История..., vol. I, pars 2, p. 636.

83 Д. АНГелов, Комит..., p. 384.

${ }^{84}$ See V. GJuselev, Bulgarisch-Fränkische beziehungen in der Ersten Hälfte des IX Jhs., BBg 2, 1966, p. 15-39; W. PoHL, Die Awaren. Ein Steppevolk in Mitteleuropa 567-822 n. Chr., München 2002, p. 327.
} 
within eight years subdued [the Avars] in such a manner that he did not allow even small traces of them to remain. But the Bulgarians he left because after the destruction of the Huns it seemed to him they were not the least dangerous to the Frankish Kingdom ${ }^{85}$. This evidence was already put into scholarly circulation by Zlatarski as further proof of the existence of a common border between Bulgaria and the Frankish Empire as early as after 805, during Khan Kroum's reign ${ }^{86}$. Even if the thesis about such an early common border between the two states (as early as circa 796) is not accepted, one could hardly deny the possibility of contacts between the two states and even skirmishes between Bulgarian and Frankish detachments during the actions of annexing the territories of the Avar Khaganate by the two states and the division of the Avar legacy ${ }^{87}$. It is precisely in these circumstances that the Bulgarians may have first acquainted themselves with the structure of the Frankish border districts - the marches, specifically, the closest to the newly acquired territories Avar March.

Later, in connection with the conflict about the Slavic tribes - the Timociani and others ${ }^{88}$, along the western Bulgarian limits who broke away from Bulgarian authority, the two states maintained constant contact through emissaries ${ }^{89}$. Reaching the year 827, after the failed attempt to find a diplomatic solution to the problem about these tribes which concerned both states, the Bulgarian side sent a military corps transported by ships along the River Drava. There the Bulgarian forces conquered with fire and sword the Slavs who lived in Pannonia, banished their princes and appointed Bulgarian governors (expulsis eorum ducibus, Bulgaricos super eos rectores constituerunt $)^{90}$.

Some scholars believe that the acts mentioned above can be seen as the appointing of local komiti on the part of the Bulgarian state ${ }^{91}$. The Bulgarian acts in Pannonia of replacing the local leaders with governors appointed by the central

\footnotetext{
${ }^{85}$ Scriptores rerum Germanicarum, Nova series (SS rer. Germ. N.S.), vol. XII, Notkeri Balbuli, Gesta Karoli Imperatoris, Berolini 1959, col. 51; MonaChus SANGALLEnsis, [in:] FLHB, vol. II, p. 285.

${ }^{86}$ В.Н. ЗлАТАРСКИ, История..., vol. I, pars 2, p. 248.

${ }^{87}$ A similar view is held by Pl. Pavlov who believes that the Bulgarian intervention in this conflict was perceived as a hostile act by the Franks. See Пл. ПАвлов, Политическото наследство на Аварския хаганат и българските владетели (IX-XI в.), [in:] ППИК, vol. III, p. 59. On the Bulgarian participation in the division of the Avar legacy and the subjugation of the Avars by the Bulgarians, see note 56 above.

${ }^{88}$ R. RAU, Quellen zur karolingischen Reichsgeschichte, vol. I, Die Reichsannalen. Einhard: Leben Karls des Großen. Zwei „Leben” Ludwigs. Nithard: Geschichten, Darmstadt 1968 [repr. 1987; = AQDGM, 5], p. 116-117; EINHARdus, [in:] FLHB, vol. II, p. 35. The number and identification of the tribes, with the exception of the Timociani, pose a problem and will be the subject of another study by the author.

${ }^{89}$ See the years 824, 825, 826 in Annales Regni Francorum; R. RAU, Quellen..., p. 138-145; EINHARDUs, p. 36-38.

${ }^{90}$ R. RAU, Quellen..., p. 150-151; EInhardus, p. 38.

${ }^{91}$ Ж. ЖЕков, България и Византия..., p. 258, 259, 260.
} 
authority seem very similar to the Frankish way of appropriating newly conquered foreign (vassal) territories. In the same manner, after the conquest of the Kingdom of the Lombards, its last king Desiderius (756-774) was removed from power and Charlemagne assumed the title of Rex Francorum et Langobardorum. In addition, Charlemagne's son Pepin was given the lands of the former kingdom as possession and was bestowed the title of King of Italy ${ }^{92}$. The same process can also be observed in Bavaria where in 788 the last of the local dynasty Duke Tassilo III was dethroned and replaced with a prefect (margrave) ${ }^{93}$.

This replacement of the local Slavic princes in Pannonia with governors appointed by the central authority can be assumed to have been the beginning of the adoption of the model of marches/komitats in early medieval Bulgaria. The course of action followed by the Bulgarian troops, the removal of the local tribal governors from power and their replacing with ones appointed by the central authority reveal even more similarities between the emergence of the first Bulgarian komitats proposed here and Frankish marches.

For further support for the advanced thesis we must go back to the correspondence noticed by Venedikov - that in Latin komit and komitat mean 'count' and 'county' respectively. Referring to the relevant Frankish official texts of the time, we only need to see Annales Regni Francorum by Einhard, which, for the year 826, describing the relations with the Bulgarians, mentions rumours that have spread that the Bulgarian ruler was dethroned or killed by one of his boyars, and further also about Bulgarian troops advancing towards the Frankish borders. In order to check whether the rumours were true towards the Pannonian border, which was the main point of contention in the Bulgarian-Frankish dispute, the count palatine Bertrich was sent to the counts in charge of the Avar March, Balderich and Gerold. The titles of the three are written in the Latin text as comites, as is the Latin spelling of the Bulgarian komiti $i^{94}$.

The existence of komitats and komiti can be established along the western Bulgarian border (the events examined above), along the north-eastern border (the case of the flight of the Byzantine settlers in 'Bulgaria beyond the Danube'), while the most abundant evidence exist about the south-western territories of the state from the time of Prince Boris' reign to the second half of the $10^{\text {th }}$ century ${ }^{95}$. It is worth noting that no record of the presence of such officials or a komitat exists about the border most critically important with respect to conflicts - the south-eastern one, leading to the capital of Byzantium. On the one hand, this seems strange, but on the other, it might be that these were not established intentionally. It is most likely that immediately after they have been conquered, these territories

92 J.M.H. SмIтн, Fines Imperii..., p. 170.

${ }^{93}$ Ibidem, p. 170; H. Wolfram, The Creation..., p. 237.

${ }^{94}$ R. RAU, Quellen...., p. 144-145; EInHardus, p. 37-38.

${ }^{95}$ On the identification and location of the particular komiti see Т. СлавовА, Владетел..., p. 156-157. 
were made directly subordinate to the central authority in the Bulgarian state as they were fiercely disputed by the two neighbours. In this way, when circumstances dictated, the central authority was able to react swiftly and repel attacks from Byzantium ${ }^{96}$. It is this direct subordination, although in a wartime situation, that is reflected in the Hambarli inscription ${ }^{97}$, which tells us that the ruler's brother was appointed commander of the army's centre (and commanding the whole army), while the kavhan and the ichirgu-boila were subordinate to him ${ }^{98}$. These territories were too close to the heart (the capital, whether Pliska or Preslav) of the Bulgarian state to be left to local governance, that is, for a komitat to be set up. With indirect governance (by means of a komitat) these territories became more vulnerable and more difficult to control. This accounts for the lack of evidence about komitats from Byzantine sources.

Directly related to the problem of komitats is also the problem about the oftmentioned both in Byzantine ${ }^{99}$ and Bulgarian ${ }^{100}$ narratives and in Proto-Bulgarian inscriptions ${ }^{101}$ terms 'inside' and 'outside'. Alexander Gilferding was the first to turn his attention to the use of the concepts 'outside' and 'inside', relating them to the central district of the state and the border districts ${ }^{102}$. Zlatarski did not fail to notice these antipodes either, devoting them a special article in which he examined the correspondences between the appellations used when addressing part of the boyars in the Book of Ceremonies of Constantine VII and the use of the same terms in the Miracle of Saint George with a Bulgarian ${ }^{103}$. According to his definition

\footnotetext{
${ }^{96}$ On the presence of Bulgarian garrisons along the Byzantine border manned by population resettled from the central parts of Bulgaria, see Б. Борисов, До тук стига България (Бележки по хронологията и развитието на селищната мрежа в Южна Бблгария по времето на Пгрвото българско иарство), [in:] Оттука започва България. Материали от втората национална конференция по история, археология и културен туризбм „Пбтуване кбм Бблгария” - Шу мен, 14-16.05.2010 година, еd. Ив. ЙордАнов, Шумен 2011, р. 231-251; IDEм, Археологические свидетельства праболгарского присуствия на юге Балкан, ПАрх 2, 2, 2012, p. 50-65; IDEм, Археологически данни за българо-византийските отночения през Ранното средновековие от територията на днешна Южна България (VII - третата четвърт на X в.), Епо 26, 2, 2018, p. 373-382.

${ }_{97}$ В. БЕшевлиЕв, Първобългарски надписи..., p. 186-187.

${ }^{98}$ Ibidem, p. 191.

${ }^{99}$ Constantine Porphyrogennetos: The Book of Ceremonies, trans. A.M.M. TALL, Leiden-Boston 2017 [= BAus, 18], p. 681; Constantini Porphyrogeniti III. De ceremoniis aulae byzantinae, [in:] FGHB, vol. V, p. 222. The expression in which these terms occur is rendered in the English translation as How are the rest of the boyars, both within [the court] and outside?

${ }^{100}$ А. КАлоянов, М. СПасова, Т. Моллов, „Сказание за железния кргст” и епохата на иар Симеон, Велико Търново 2007, р. 198; Я. Христов, Щрихи към „Сказание за железния крғст”, Благоевград 2012, р. 34-35.

${ }^{101}$ See, e.g., В. БЕшевлиев, Първобългарски надписи..., p. 235-237 (nos. 65, 66).

102 А.Ф. Гильфердингъ, Собрание сочинений, vol. I, pars 1, История сербовъ и болгаръ, pars 2, Кирилль и Мебодий, pars 3, Обзоръ чешской истории, Санктъ Петербургъ 1868, p. 28.

${ }_{103}$ В.Н. ЗЛАТАРСКИ, Кои са бИли вбтрещни и вбнщни боляри?, [in:] IDEM, Избрани произведения, vol. I, ed. П. ПЕтров, София 1972, p. 298-312.
} 
of the two terms, the 'Inner' Boyars were those who lived 'inside' the ruler's residence, while the 'Outer' Boyars were those who did not hold an office with the ruler, that is, did not hold a position of power, but lived 'outside' the centre of the state on estates of their own, always ready, however, to come to the state's aid ${ }^{104}$. This problem is more thoroughly discussed by Venedikov. Examining the revolt of the boyars after the conversion to Christianity, based on Hincmar's account and the Responsa Nicolai papae ad consulta Bulgarorum, he arrives at the conclusion that the rebel forces came from the komitats. He also makes another important point - apparently, at that time the Bulgarian ruler had a large and powerful army at his disposal to resist the troops coming from the komitats, which, to him, offers proof of the existence of an inner district ${ }^{105}$. Considering the evidence provided by Constantine Porphyrogennetos about the Inner and Outer Boyars, and making an allusion to Byzantium where Constantinople was 'inside', and the themes (provinces) were 'outside', he notes that some scholars assume that 'inside' Bulgaria is to be understood as the capital (Pliska, Preslav, or Ohrid), while 'outside' were the komitats. He also wonders why Gilferding understands 'outside' as border districts, since, in this case, 'inside' should not be understood as the capital, but as the inner district of the state. To Venedikov, this is in contradiction with the idea that Bulgaria was organized like Byzantium, but was rather like the Frankish state and its marches ${ }^{106}$. Zhekov is skeptical about the existence of an inner district in the early medieval Bulgarian state, and thinks that the terms 'inside' and 'outside' used in Proto-Bulgarian inscriptions refer to whether the particular commander was killed within the limits of the state or outside it. He is similarly skeptical about the interpretation of the text of Constantine Porphyrogennetos ${ }^{107}$.

It is evident from the views discussed above that there is a difference of opinion as to what is to be understood by 'inside' and 'outside' with regard to the early medieval Bulgarian state. If we assume that 'inside' was understood as the capital, this will imply a great concentration of power in the centre and a number of semi-independent aristocrats gravitating for various reasons towards the authority in the capital. More likely seems the possibility that 'inside' was the central district of the state, the nucleus around which the gradually expanding state was built, and around the state were the 'outer' districts. These districts 'outside' do not in the least rule out the possibility of their being the komitats (which Venedikov is unwilling to assume), which were territories incorporated additionally into the state also serving border-guarding functions. In this case too, the similarity with the Frankish state itself invites comparison. There, the traditionally used

\footnotetext{
${ }^{104}$ Ibidem, p. 309.

${ }^{105}$ Ив. ВенедИков, Военното..., р. 18.

${ }^{106}$ Ibidem, p. 20-21.

107 Ж. ЖЕков, България и Византия..., p. 283-284.
} 
ruler's formula was: both within the kingdom and outside it in our marches ${ }^{108}$. Thus, marches and komitats reveal still more similarities, while the differences from the supposed Byzantine model of komitats become even more significant.

The earthen ramparts, as Koledarov believes, can be assumed to have been marking the territory 'inside' the state, clearly indicating the location of this central part on the two banks along the lower reaches of the River Danube ${ }^{109}$.

$$
* * *
$$

Over and over again in Bulgarian historiography after Zlatarski ${ }^{110}$ and particularly after Y. Andreev ${ }^{111}$, the position has been consistently adopted that komiti were not directly subordinate to the ruler and the central authority, but to another institution - boritarkhans ${ }^{112}$. Zhekov holds a different opinion, drawing attention to the fact that the Bopıтaká $\gamma \gamma \omega$ (boritarkhan) ${ }^{113}$ in Belgrade, mentioned by Theo-

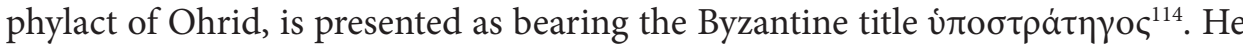
disagrees with Venedikov's interpretation that the terms stratigos and ypostratigos were synonymous and it 'cannot be a matter of dispute' that they denoted governor of a theme (district) ${ }^{115}$. In Zhekov's opinion, there was only one isolated case in which an ypostratigos performed the functions of governor of a theme, and in most of the cases described, this title was only borne by active military commanders ${ }^{116}$. In the context of the establishing of the Theme of Thrace, Nikolay Kanev also observes that the earliest attested high-ranking Byzantine administrator in charge of the theme (the same one whom Zhekov defines as the sole exception) was Theodor, the apo hypaton, patrikios, komes of the imperial Opsikion and the ypostratigos of Thrace ${ }^{117}$. To him, in the case of Theodor, within the

\footnotetext{
${ }^{108}$ Capitularia Hlotharii I. et regnum Italiae (no. XV), 851. aestate, [in:] MGH.Ca, vol. II, p. 74, 17-18 (no. 205, Hlotharii, Hludowici et Karoli conventus apus marsnam secundus; Adnuntiatio Hlotharii): et infra regnum et extra regnum per marchas nostras; English translation - J.M.H. SMith, Fines Imperii..., p. 177.

${ }^{109}$ П. КолЕДАРОв, Политическа геограбия..., p. 14.

${ }^{110}$ В.Н. ЗЛАТАРСКИ [rec.], Г. БАЛАСЧЕВ..., p. 30-33.

${ }^{111}$ Й. Андревв, Нарышская надпись князя Симеона и административное устройство болгарского государьства в коние IX и начале X в., ЕВ 14, 3, 1978, p. 121-131.

${ }^{112}$ See Gy. Moravcsiк, Byzantinoturcica, vol. II, Berlin 1958, p. 97, 166, 299-300, 355; Хр. КолАРов, Средновековната българска държава..., p. 8; Ив. Венедиков, Военното..., p. 57-62; Г. Николов, Централизбм и регионализбм..., р. 89.

${ }^{113}$ I. ILIEv, The Long Life of Saint Klement of Ochrid. A Critical Edition, BBg 9, 1995, p. 97, 673.

${ }^{114}$ Ibidem, p. 97, 677; Vita s. Clementis Achridensis, [in:] FGHB, vol. IX, pars 2, p. 30; Ж. Жеков, България и Византия..., р. 283.

${ }^{115}$ Ив. ВенЕдИков, Военното..., р. 59.

116 Ж. Жеков, България и Византия..., p. 283.

${ }^{117}$ Н. Кънев, Мястото на стратегията на Тракия във византийската рангова йерархия през IX-X в. според тактиконите от това време, [in:] IDEм, Византинобългарски студии, Велико
} 
context of the Byzantine administrative-rank system he should be interpreted not in the sense of deputy stratigos, but as 'acting' this function during the absence of the office holder ${ }^{118}$. It seems even stranger for an ex-consul and patrikios, such as Theodor, who had been put in charge of a separate theme like Opsikion, to have been subordinate to another head of theme $\mathrm{e}^{119}$. By ypostratigos is to be understood the office of the sub-stratigos, directly subordinate to the stratigos and substituting for him in some functions ${ }^{120}$. More particularly, the function of the stratigos was governor of a theme and military leader of the troops at his command ${ }^{121}$. Therefore, the designation of the boritarkhan/tarkhan as sub-stratigos in the life of St. Clement of Ohrid can serve as a point of reference in defining his official position as against the Byzantine hierarchical system. On these grounds, it could be asserted with reasonable certainty that the order of the rank subordination did not descend from boritarkhan to komit, but vice versa. The fact that they are mentioned in reverse order (immediately after the ruler follows the boritarkhan and then the komit) in the inscription of $\mathrm{Narash}^{122}$ can be interpreted in the sense that the direct responsibility for this sector of the border rested with the tarkhan, who was subordinate to the komit. Furthermore, their being referred to together in this inscription is further proof that these two offices combined both military and administrative functions.

\section{$* * *$}

The thesis about the origins of komitats advanced here relates komitats in a number of aspects to the marches that emerged earlier in Charlemagne's state. Available evidence and the analogies from the Frankish context make it possible for them to be described as separate districts situated at the periphery of the state, governed by komiti directly appointed by the ruler. And as Kolarov puts it, like a wreath, they surrounded the Bulgarian lands in Moesia ${ }^{123}$. Their emergence can be linked to the Bulgarian-Frankish conflict over the Slavic tribes that broke away from Bulgaria, which was ended with the replacing of their leaders with governors appointed by the central authority. We do not have any evidence of the existence of komitats in a south-easterly direction - towards the capital of Byzantium - the major conflict zone in the international relations of the First Bulgarian Empire. These territories, as well as the territories constituting the core

Търново 2013, p. 130-131, fn. 2; G.D. MANsI, Sacrorum consiliorum nova et amplissima collection, vol. XI, Leipzig 1901, p. 209.

${ }^{118}$ Н. Кънев. Мястото на стратегията..., p. 130-131, fn. 2.

${ }^{119}$ Ibidem.

${ }^{120}$ Ibidem.

${ }^{121}$ Ibidem.

${ }^{122}$ В. Бешевлиев, Първобългарски надписи..., p. 182-185 (nо. 46); Й. АндРеЕв, Нарышская надпись...

${ }^{123}$ Хр. КолАРов, Средновековната българска държава..., р. 8. 
of the early medieval Bulgarian state, were under the direct control of the central authority and were often referred to by the term 'inside', in contradistinction to 'outside' which denoted komitats.

The introduction of an administrative division into the Bulgarian state on the model of the Frankish state ensured secure control at the periphery of the state when there was a strong central authority, but with a weak central authority and relaxed controls over the border districts, it would contribute to the increase of the centrifugal forces.

\section{Bibliography}

\section{Primary Sources}

Annales Bertiniani, praef., trans. et comm. Str. LIšEv, [in:] Fontes Latini Historiae Bulgaricae, vol. II, ed. Iv. DujČEv et al., Serdicae 1960, p. 286-288.

BešEvliev V., Părvobălgarski nadpisi, ${ }^{2}$ Sofija 1992.

Capitularia Hlotharii I. et regnum Italiae (no. XV), [in:] Monumenta Germaniae historica, Legum sectio II. Capitularia regum Francorum, vol. II, ed. A. BoretiUs, V. KRAUSE, Hannoverae 1897, p. 59-110.

Constantine Porphyrogennetos: The Book of Ceremonies, trans. A.M.M. TALL, Leiden-Boston 2017 [= Byzantina Australiensia, 18].

Constantini Porphyrogeniti III. De ceremoniis aulae byzantinae, praef., trans. et comm. G. CANKova-Petkova, P. Tivčev, [in:] Fontes Graeci Historiae Bulgaricae, vol. V, ed. G. Cankova-Petkova et al., Serdicae 1964, p. 220-229.

EINHARdus, praef., trans. et comm. Str. LišEv, [in:] Fontes Latini Historiae Bulgaricae, vol. II, ed. Iv. DujČEv et al., Serdicae 1960, p. 29-39.

Georgius Monachus Continuatus, praef., trans. et comm. G. Cankova-Petkova, [in:] Fontes Graeci Historiae Bulgaricae, vol. VI, ed. G. Cankova-Petkova et al., Serdicae 1965, p. 133-158.

Iliev I., The Long Life of Saint Klement of Ochrid. A Critical Edition, "Byzantinobulgarica” 9, 1995, p. $62-120$.

Kalojanov A., Spasova M., Mollov T., „Skazanie za železnija krast” i epohata na car Simeon, Veliko Tărnovo 2007.

Leonis Grammatici Chronographia, praef., trans. et comm. V. TĂpкova-Zaimova, [in:] Fontes Graeci Historiae Bulgaricae, vol. V, ed. G. Cankova-Petкova et al., Serdicae 1964, p. 141-168.

MANsi G.D., Sacrorum consiliorum nova et amplissima collection, vol. XI, Leipzig 1901.

Monachus Sangallensis, praef., trans. et comm. Str. Lišev, [in:] Fontes Latini Historiae Bulgaricae, vol. II, ed. Iv. DujčEv et al., Serdicae 1960, p. 282-285.

Pseudo-Symeonis Chronographia, praef., trans. et comm. G. Cankova-Petrova, [in:] Fontes Graeci Historiae Bulgaricae, vol. V, ed. G. Cankova-Petкova et al., Serdicae 1964, p. 169-182.

Scriptores rerum Germanicarum, Nova series (SS rer. Germ. N.S.), vol. XII, Notkeri Balbuli, Gesta Karoli Imperatoris, Berolini 1959.

Suda Online http://www.stoa.org/sol/ [15 VIII 2018]. 
Suidae Lexicon, praef., trans. et comm. G. Cankova-Petkova, [in:] Fontes Graeci Historiae Bulgaricae, vol. V, ed. G. Cankova-Petkova et al., Serdicae 1964, p. 308-310.

Theophanes Confessor, trans. V. Beševliev, G. Cankova-Petkova, praef. et comm. G. Cankova-Petkova, [in:] Fontes Graeci Historiae Bulgaricae, vol. III, ed. Iv. DujčEv et al., Serdicae 1960, p. 226-289.

Vita s. Clementis Achridensis, [in:] Fontes Graeci Historiae Bulgaricae, vol. IX, Theophylacti Achridensis, archiepiscopi Bulgariae, scripta ad historiam Bulgariae pertinentia, pars 2, Vita s. Clementis Achridensis, Historia martyrii XV martyrum Tiberiupolitanorum, epistulae, carmen ad Nicephorum Bryennium, pars expositionis in epistulam Pauli apostoli ad Romanos, ed. I.G. ILIEv, Serdicae 1994, p. 10-41.

\section{Secondary Literature}

Andreev J., Naryšskaja nadpis' knjazja Simeona i administrativnoe ustrojstvo bolgarskogo gosudar'stva v konce IX i načale X v., "Études Balkaniques" 14, 3, 1978, p. 121-131.

Andreev M., Milkova F., Istorija na bălgarskata feodalna dăržava i pravo, Sofija 1993.

Angelov D., Administrativno-voenna uredba, [in:] Istorija na Bălgarija v četirinadeset toma, vol. II, Părva bălgarska dăržava, ed. D. ANGELov, Sofija 1981, p. 169-181.

Angelov D., Komit, [in:] Kirilo-Metodievska Enciklopedija, vol. II, I-O, ed. P. Dinekov, Sofija 1995, p. 384 .

Angelov D., Andreev M., Istorija na bălgarskata dăržava i pravo, Sofija 1972.

Borisov B., Archeologičeskie svidetel'stva prabolgarskogo prisustvija na juge Balkan, “Поволжская археология" / "Povolžskaja archeologija" 2, 2, 2012, p. 50-65.

BoRIsov B., Arheologičeski danni za bălgaro-vizantijskite otnošenija prez Rannoto srednovekovie ot teritorijata na dnešna Južna Bălgarija (VII - tretata četvart na X v.), "Епохи" / "Epohi” 26, 2, 2018, p. 373-382.

Borisov B., Do tuk stiga Bălgarija (Beležki po hronologijata i razvitieto na selištnata mreža v Južna Bălgarija po vremeto na Părvoto bălgarsko carstvo), [in:] Ottuka započva Bălgarija. Materiali ot vtorata nacionalna konferencija po istorija, arheologija i kulturen turizăm „Pătuvane kăm Bălgarija” - Šumen, 14-16.05.2010 godina, ed. Iv. Jordanov, Šumen 2011, p. 231-251.

Bowlus C.R., Franks, Moravians, and Magyars: The Struggle for the Middle Danube, 788-907, Philadelphia 1995.

BožIlov Iv., GJuZelev V., Istorija na srednovekovna Bălgarija VII-XIV vek, Sofija 1999.

Bugarski I., Radišić M., The Central Balkans in the Early Middle Ages: Archaeological Testimonies to Change, [in:] Byzantine Heritage and Serbian art, vol. I, Process of Byzantinisation and Serbian Archaeology, ed. V. Bikić, Belgrade 2016, p. 91-99.

Bury J.B., A History of the Eastern Roman Empire from the Fall of Irene to the Accession of Basil I (A.D. 802-867), London 1912.

DAšKov S.B., Imperatory Vizantii, Moskva 1996.

Dictionary of the Middle Ages, vol. VIII, Macbeth - Mystery plays, New York 1987.

GIL'Ferding A.F., Sobranie sočinenij, vol. I, pars 1, Istorija serbov i bolgar, pars 2, Kirill i Mefodij, pars 3, Obzor českoj istorii, Sankt Peterburg 1868.

GJuselev V., Bulgarisch-Fränkische beziehungen in der Ersten Hälfte des IX Jhs., "Byzantinobulgarica" 2, 1966, p. 15-39. 
Hrissimov N., Bălgarskata dăržavnost v starata Rodina (VII-XI B.): taka narečenata Černa Bălgarija, [in:] Bălgarska nacionalna istorija, vol. II, Drevnite bălgari. Stara Velika Bălgarija, ed. Pl. PAVlov, Veliko Tărnovo 2013, p. 249-296.

Hristov Ya., Štrihi kăm „Skazanie za železnija krăst”, Blagoevgrad 2012.

ILIEv I., The Long Life of Saint Klement of Ochrid. A Critical Edition, "Byzantinobulgarica” 9, 1995, p. 62-120.

KăNev N., Mjastoto na strategijata Trakija văv vizantijskata rangova jerarhija prez IX-X v. spored taktikonite ot tova vreme, [in:] N. KăNEv, Vizantinobălgarski studii, Veliko Tărnovo 2013, p. 129-143.

Kolarov Hr., Srednovekovnata bălgarska dăržava (uredba, harakteristika, otnošenija săs săsednite narodi), Veliko Tărnovo 1977.

Koledarov P., Političeska geografija na srednovekovnata bălgarska dăržava, vol. I, (679-1018), Sofija 1979.

Komar O.V., Chozars'kij kaganat u VIII-X st., [in:] Ukraïna: chronologija rozvitku. Davni slov'jani ta Kiïvs'ka Rus', vol. II, ed. P. ToločKo, G. Ivakin, O. Mocja, Kiïv 2009, p. 118-125.

Kozlov V., Naselenie stepnogo meždurečja Dunaja i Dniestra konca VIII - načala XI vekov n.je.: balkano-dunajskaja kul'tura, Kazan'-Sankt-Peterburg-Kišinev 2015.

KulakovsкiJ Ju.A., Istorija Vizantii, vol. III, (602-717 gg.), Kiev 1915.

Lexikon des Mittelalters, vol. III, Codex Wintoniensis bis Erziehungs- und Bildungswesen, Stuttgart 1986.

Lexikon des Mittelalters, vol. VI, Lukasbilder bis Plantagenêt, Stuttgart 1993.

MARINOw K., Góry Hemos jako miejsce schronienia, baza wypadowa i punkt obserwacyjny w świetle bułgarsko-bizantyńskich zmagań zbrojnych okresu wczesnego średniowiecza, "Balcanica Posnaniensia" 20, 2013, p. 5-17.

Marinow K., The Haemus Mountains and the Geopolitics of the First Bulgarian Empire: An Overview, “Зброник радова Византолошког института" / "Zbornik radova Vizantološkog instituta” 51, 2014, p. 17-32.

MARINow K., Planinskata veriga Hemus i bălgarskata političeska granica prez rannosrednovekovnija period (Obšt pogled), [in:] Balkanite - ezik, istorija, kultura, vol. IV, Materiali ot Četvartata meždunarodna naučna konferencija „Balkanite - ezik, istorija, kultura”, Veliko Tărnovo, 18-20 oktomvri 2013 g., ed. Kr. Mutafova, Veliko Tărnovo 2015, p. 105-120.

MARINOW K., Strategičeskata rolja na Staroplaninskata i Srednogorskata verigi v svetlinata na bălgaro-vizantijskite voenni sblăsăci prez VII-XI vek, "Известия на Регионалния исторически музей - Габрово" / "Izvestija na "Regionalnija istoričeski muzej - Gabrovo" 2, 2014, p. 111-134.

MARINOw K., $V$ derbite na Hemus (Za njakoi strani v roljata na planinata prez perioda VII-IX v.), "Palaeobulgarica" 37, 4, 2013, p. 60-73.

Milkova F., Zakonodatelstvoto na han Krum, [in:] Bălgarija 1300. Institucii i dăržavna tradicija, vol. II, ed. Ev. Buzaski, Sofija 1982, p. 235-244.

Moravcsik Gy., Byzantinoturcica, vol. II, Berlin 1958.

MutafČıev P., Balkanăt v našata istorija, [in:] P. MutafČıev, Kniga za bălgarite, ed. V. GJuzelev, Sofija 1987, p. 65-89.

Nikolov G.N., Centralizăm i regionalizăm v rannosrednovekovna Bălgarija (kraja na VII - načaloto na XI v.), Sofija 2005.

Ostrogorski G., Istorija na Vizantijskata dăržava, trans. Il. Slavova, Sofija [s.a.].

Pavlov Pl., Političeskoto nasledstvo na Avarskija haganat i bălgarskite vladeteli (IX-XI v.), [in:] Problemi na prabălgarskata istorija i kultura, vol. III, ed. R. RAšEv, Sumen 1997, p. 55-66. 
PонL W., Die Awaren. Ein Steppevolk in Mitteleuropa 567-822 n. Chr., München 2002.

RAU R., Quellen zur karolingischen Reichsgeschichte, vol. I, Die Reichsannalen. Einhard: Leben Karls des Großen. Zwei „Leben” Ludwigs. Nithard: Geschichten, Darmstadt 1968 [repr. 1987; = Ausgewählte Quellen zur deutschen Geschichte des Mittelalters, 5].

Slavova T., Vladetel i administracija v rannosrednovekovna Bălgarija. Filologičeski aspekti, Sofija 2010.

Sмiтн J.M.H., Fines Imperii: The Marches, [in:] The New Cambridge Medieval History, vol. II, c. 70-900, ed. R. McCormick, Cambridge 2008, p. 169-189.

Stankov R., O leksičeskich moravizmach v drevnich slavjanskich rukopisjach, [in:] Preslavska knižovna škola, vol. IX, ed. M. Tinova, Šumen 2006, p. 29-52.

Venedikov Iv., Administrativna uredba na Părvata bălgarska dăržava, [in:] Bălgarija 1300. Institucii i dăržavna tradicija, vol. I, ed. Ev. BUŽAski, Sofija 1981, p. 139-159.

Venedikov Iv., Voennoto i administrativnoto ustrojstwo na Bălgarija prez IX i X vek, Sofija 1979.

Wasilewski T., Origine de l'organisation administrative des "comitates" en Bulgarie medievale, "Études Balkaniques" 14, 1, 1978, p. 84-88.

Wolfram H., The Creation of the Carolingian Frontier-System c. 800, [in:] Transformation of Frontier from Late Antiquity to Carolingians, ed. W. Pohl, I. Wood, H. Reimitz, Leiden-Boston 2001, p. 233-260.

Zlatarski V.N., Istorija na bălgarskata dăržava prez srednite vekove, vol. II, Părvo bălgarsko carstvo, pars 2, Ot slavjanizacijata na dăržavata do padanaeto na Părvoto carstvo, Sofija 1927 [repr. 1994].

Zlatarski V.N., Koi sa bili vatrešni i vanšni boljari?, [in:] V.N. Zlatarski, Izbrani proizvedenija, vol. I, ed. P. Petrov, Sofija 1972, p. 298-312.

Zlatarski V.N. [rec.] Balasčev G., Novonajdenijatz nadpisz otz vremeto na carb Simeona... - “Сборник за Народни умотворения, наука и книжнина" / "Sbornik za Narodni umotvorenija, nauka i knižnina” 15,1898 , p. 20-40.

ŽEкоv Ž., Bălgarija i Vizantija. Voenna administracija VII-IX v., Sofija 2007.

Abstract. The article gives a critical review of previous views on the origin of komitats as administrative units in the Early Medieval Bulgarian State. Among the Bulgarian researchers, the opinion of their Byzantine origin prevailed, while the only Western researcher dealing with the problem, T. Wasilewski, advocated the thesis of their relationship with Western Europe, suggesting some of the conclusions of I. Venedikov. It is concluded that at the beginning of the $9^{\text {th }}$ century, when Bulgaria expanded its territory almost doubled, its population is multiethnic and already has direct neighbors in the face of Byzantium and the Frankish state needed a new administrative division. The administrative division of the two countries is decided in two fundamentally different ways. In search of ways to solve the problem, the Byzantine themae system and the marks of the Frankish state are presented. Between komitats and the themae system the similarities are only formal, whereas the comparison with the marks proved to be much more efficient. In this case, similarities are found with regard to their location, their way of setting up, the powers and the way of appointing their governors, as well as the names and powers of the governors. The presence of komitats on the northern and western borders of the Early Medieval Bulgarian state was established, but not in the direction of Constantinople. These parts are directly subordinate to the central government, and this division of 'inside' and 'out' is characteristic of both early-medieval Bulgaria and the Frankish state of that period. It is 
pointed out the possibility that the Boritarkans are an intermediary between the central authority and the komitats, and on the basis of the source data the possibility is presented that they are directly subordinated to the komiti.

Keywords: First Bulgarian Empire, Byzantium, Frankish state, komitats, marks, administrative units, comes, komit.

Nikolay Hrissimov

St. Cyril and St. Methodius University of Veliko Tărnovo

Faculty of History

Department of Ancient and Medieval History

Teodosiy Tarnovski 2

5000 Veliko Tărnovo, Bulgaria

hrissimov@gmail.com 